\title{
Intraoperative Anaphylactic Shock Following Cefuroxime-Axetil Routine Test \\ Case report and literature review
}

\begin{abstract}
MIRELA TIGLIS ${ }^{1,2 *}$, ANDREEA MESTER ${ }^{1}$, TUDOR HURMUZACHE ${ }^{1}$, CAMELIA CRISTINA DIACO NU ${ }^{3,4}$, RAZVAN ION FLORIN DRAGOMIRESCU, LOREDANA MIHAELA OPREA ${ }^{1}$, OVIDIU GABRIEL BRATU5,7, TIBERIU PAUL NEAGU 8,9 , BO GDAN SOCEA ${ }^{10,11}$, IOAN LASCAR ${ }^{8,9}$, IO ANA MARINA GRINTESCU1,2

'Department of Anesthesiology and Intensive Care, Emergency Clinical Hospital of Bucharest, 8th Floreasca Av., 014461, Bucharest, Romania

${ }^{2}$ Carol Davila University of Medicine and Pharmacy Bucharest, Clinical Department No. 14, 8 Eroii Sanitari Str., 050474, Bucharest, Romania

${ }^{3}$ Department of Internal Medicine, Emergency Clinical Hospital of Bucharest, 8th Floreasca Av., 014461, Bucharest, Romania ${ }^{4}$ Carol Davila University of Medicine and Pharmacy, Clinical Department No. 5, 8th Eroii Sanitari Str., 050474, Bucharest, Romania ${ }^{5}$ Carol Davila University of Medicine and Pharmacy, Clinical Department No. 3, 8th Eroii Sanitari Str., 050474, Bucharest, Romania ${ }^{6}$ Department of Nephrology and Dialysis, "St. John" Emergency Clinical Hospital, 13 ${ }^{\text {th }}$ Vitan-Barzesti Road, 042122, Bucharest, Romania

Department of Urology, Carol Davila University Emergency Central Military Hospital, 88th Mircea Vulcanescu Str., 010825, Bucharest, Romania

${ }^{8}$ Department of Plastic Surgery and Reconstructive Microsurgery, Emergency Clinical Hospital of Bucharest, 8th Floreasca Av., 014461, Bucharest, Romania

${ }^{9}$ Carol Davila University of Medicine and Pharmacy, Clinical Department No. 11, 8th Eroii Sanitari Str., 050474, Bucharest, Romania

${ }^{10}$ Department of Surgery, Sf. Pantelimon Emergency Universitary Hospital, 340-342nd Pantelimon Road, 021623, Bucharest, Romania

${ }^{11}$ Carol Davila University of Medicine and Pharmacy, Clinical Department No. 10, 8th Eroii Sanitari Str., 050474, Bucharest, Romania
\end{abstract}

Approximately $72 \%$ of patients with anaphylaxis present cardio-vascular manifestations, with only few reported cases of cardiogenic shock and cardiac arrest. Cephalosporins are the most used antibiotics for prophylaxis in the perioperative period with a prevalence of allergic reactions between 1-3\%. Cefuroxime, a second-generation semisynthetic cephalosporin, presents relatively rare anaphylactic reactions $(0.015 \%)$. Kounis syndrome is characterized by appearance of acute coronary syndrome in the presence of platelets, basophils or mast cells activation, due to an allergic reaction, hypersensitivity, anaphylactic reaction or shock. We reporta rare case of a 53-year-old female patient with intraoperative anaphylactic shock following Cefuroxime-axetil routine test, complicated with Kounis syndrome and finally with cardiac arrest.

Keywords: cefuroxime, anaphylactic shock, Kounis syndrome, prone position, renal failure

Anaphylaxis (a systemic hypersensitivity reaction with potentially fatal outcome), in perioperative period, appears usually secondary to a drug allergy, with basophils and mast cells activation. It can primary affect the skin and cardiovascular system, then the kidneys, pulmonary, gastrointestinal and nervous systems [1]. Approximately $72 \%$ of patients with anaphylaxis present cardio-vascular events, with only few reported cases of cardiogenic shock and cardiac arrest. The appearance of cardiac events can be explained by generalized vasodilatation, abnormal vascular permeability, and consecutive reduction in circulating blood volume and increased cardiac contraction [2].

All beta-lactam antibiotics, principally penicillins and cephalosporins, are responsible for hypersensitivity reactions. Cephalosporins are the most used antibiotics for prophylaxis in the perioperative period, usually at the time of anesthesia induction, with a prevalence of allergic reactions between 1-3\% [3]. Cefuroxime, a secondgeneration semisynthetic cephalosporin, is utilized on a daily basis in clinical practice [4]. Anaphylactic reactions atCefuroxime administration were relatively rare $(0.015 \%)$ [5], but in the last few years, there was an increased rate of cases reported, with anaphylactic shock and Kounis syndrome appearance $[6,7]$. Allergies to Cephalosporins are usually represented by maculo-papular skin eruption, dizziness, fever, positive Coombs test, positive antiglobulin, urticaria, angioedema, rhinitis, bronchospasm, serumsickness-like reactions and anaphylaxis [6]. Extremely rare, it can manifest through renal complications, like acute interstitial nephritis or acute renal failure and drug-induced cytopenias [6-10].

Kounis syndrome, also called allergic angina, described for the first time in 1991 [11], is characterized by appearance of acute coronary syndrome in the presence of platelets, basophils or mast cells activation, due to an allergic reaction, hypersensitivity, anaphylactic reaction or shock [9]. The triggers are drugs [12-14], environmental exposure [15], chemicals [16], foreign bodies [17] and some specific diseases associated with inflammatory mediators' release [18]. When mast cells and basophils are activated, with consecutive release of inflammatory mediators, it can produce epicardial coronary arterial vasospasm or atheroma plaque ulceration or dislocation, leading to angina appearance or infarction. Therefore, there are three mechanism of Kounis syndrome: allergic angina due to coronary vasospasm, allergic myocardial infarction associated or not with coronary arterial comorbidities and stent thrombosis $[12,19]$. Based on these mechanisms, usually, there are two types of Kounis syndrome: type I, 
patients with normal epicardial coronary arteries, and type II, patients with silent atheromatous coronary artery disease [13].

Herein, we present a rare case of a patient with intraoperative anaphylactic shock following Cefuroximeaxetil routine test, complicated with Kounis syndrome and finally with cardiac arrest. There are some reported cases with cardiac events appearance after Cefuroxime administration [12, 20-22]. Although antibiotics are the most common cause of anaphylaxis during perioperative period, refractory anaphylactic shock followed by cardiac arrest with a resuscitation duration of 18 minutes is a rare situation.

\section{Experimental part}

A 53-year-old female patient with L5-S1 degenerative spondylolisthesis and secondary bilateral paresis, grade 2 arterial hypertension, diabetes mellitus type 2, dyslipidemia, morbid obesity, osteoporosis, recurrent depression disorder and history of radiation therapy for breast cancer (2013), was electively admitted in our hospital in order to perform spine stabilization. The patient doesn't have any history of food or drugs allergy. On admission, chest X-ray, electrocardiogram, spirometry and laboratory exams were within normal limits.

Perioperatively, she received midazolam, ranitidine and metoclopramide, as intravenous premedication, to improve the safety and quality of the general anesthesia. Everything was normal, so the induction phase was started. There were used commonly induction agents, such as fentanyl (synthetic opioid), propofol (sedative hypnotic), suxamethonium chloride (short acting depolarizing neuromuscular blocking agent) and after that, the endotracheal tube placement and mechanical ventilation were performed without incidents. Rocuronium was used as a long acting depolarizing neuromuscular blocking agent. The maintenance of the anesthesia was realized with a sevoflurane (volatile anesthetic agent) in a mixture with oxygen. Several monitoring technologies were used: continuous pulse oximetry, continuous electrocardiography, non-invasive blood pressure monitoring, oxygen measurements, anesthetic agent concentration measurements, capnography, train of four monitoring, temperature measurement and all types of alarms. Things went normal and the patient was put in anterior decubitus in order to perform the intervention. One vial of cefuroximeaxetil $(1500 \mathrm{mg}$ ) was diluted in $20 \mathrm{~mL}$ of normal saline solution and an intradermic skin test was performed, with negative result. After few minutes, an intravenous routine test was also performed ( $1 \mathrm{~mL}$ from the initial dilution was diluted again in $10 \mathrm{~mL}$ of saline solution and $1 \mathrm{~mL}$ of that last solution is used as intravenous test). After that, everything went in the wrong direction. Blood pressure has become undetectable with secondary unresponsive extreme bradycardia, followed by asystole and cardiac arrest. The patient was immediately turned into a dorsal decubitus and the resuscitation maneuvers were performed accordingly with the guidelines. After few minutes ventricular fibrillation was installed and sinus rhythm was obtained after 3 shocks and $300 \mathrm{mg}$ of Amiodarone (18 min). An echocardiography was performed into the operating room and severe hypokinesia of anterior and anteroseptal walls, apex and the inferior part of the interventricular septum were observed, with an ejection fraction of left ventricle of $15 \%$. Then, the patient was transferred into de ICU (Intensive Care Unit).

At admission, laboratory exams have shown severe mixed acidosis, hyperlactatemia, hypocalcemia, severe hyperglycemia, severe leukocytosis, high blood levels of urea and creatinine and positive biomarkers of cardiac ischemia. The applied therapeutic principles were correction of the hydroelectrolytic and acid-base disturbances, ventilatory support, maximal vasopressor and inotrope support, continuous analgosedation, broad spectrum antibiotherapy, ulcer and thromboembolic prophylaxis, diuretic therapy, cerebral depletion therapy, insulin therapy, systemic corticosteroid therapy, antihistamines, antioxidant therapy and dual antiplatelet therapy. A new echocardiography was performed revealing persistent dyskinesia of the $1 / 2$ apical zone and anterior wall of the left ventricle and an ejection fraction of 35\%. The cardiologist confirmed the fact that it was a type II Kounis syndrome secondary to anaphylactic shock. Due to the unfavorable evolution, a minimally invasive cardiac output monitoring was used. In the presence of severe renal injury, continuous venovenous hemodiafiltration renal replacement therapy was needed. The lactate clearance was very slow (fig. 1). The respiratory status was severe affected, with refractory hypoxemia and moderate hypercapnia. In the presence of a severe acute respiratory distress syndrome (fig. 2), prone position was used, with secondary improvements in oxygenation in the next $24 \mathrm{~h}$, leading to a reduction in the ventilatory parameters values. After four days of maximal therapies, the vasopressor and inotrope support were reduced, arterial blood gases analysis was within normal limits and analgosedation has been gradually reduced. Under continuous infusion of loop diuretics, the urinary output was increased and the renal replacement therapy was no more needed. The repeated cardiac biomarkers were within normal limits. In the seventh day of intensive care, the patient was extubated

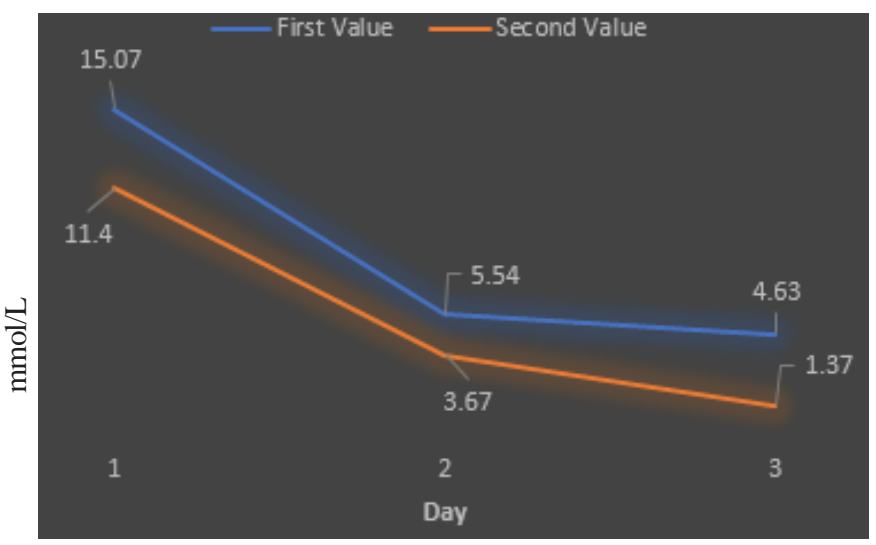

Fig. 1. Lactate clearance

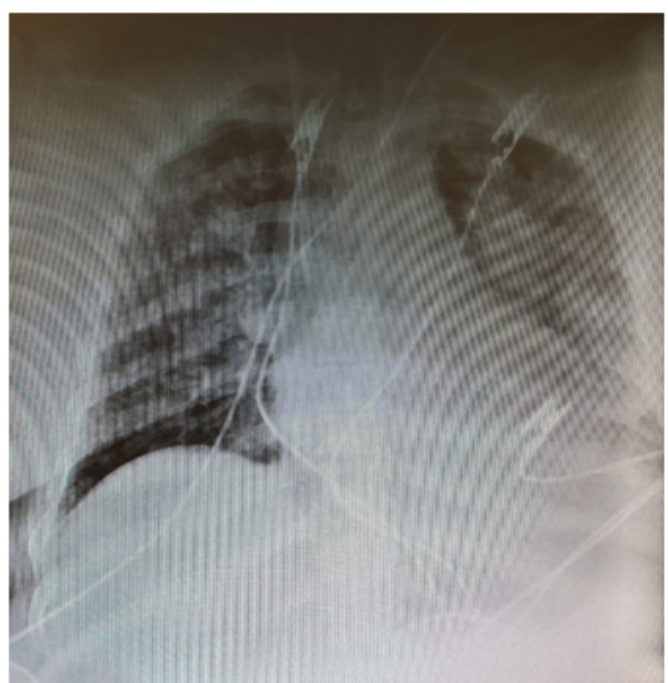

Fig. 2. Chest $\mathrm{X}$-ray revealing acute respiratory distress syndrome 
but oxygen therapy with high-flow heated humidification was used in order to maintain blood gases analysis at normal values. The patient had no neurological deficit. The leukocytosis has hardly returned to normal values (fig. 3). The last echocardiography revealed the left ventricle hypertropia without kinetic disorders and normal ejection fraction. After 14 days the patient was discharge to surgical ward for further therapeutic management.

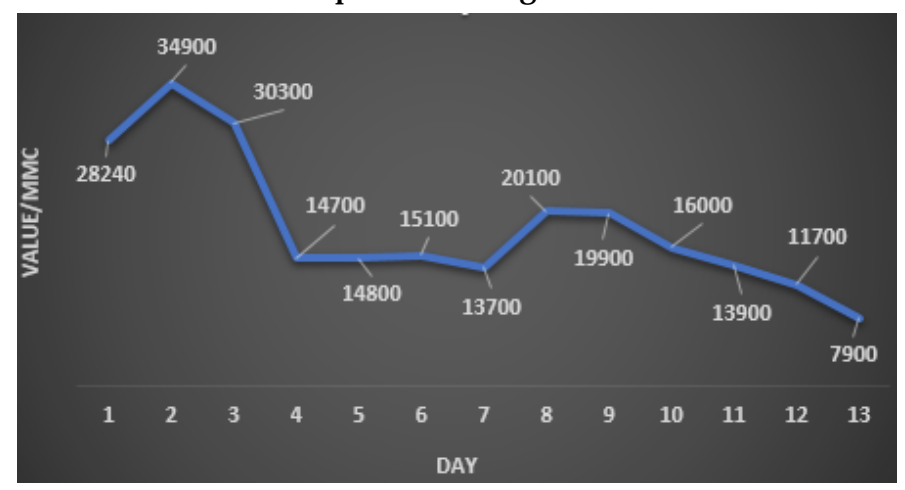

Fig. 3 Leukocytosis

\section{Results and discussions}

Betalactams are widely used to treat or to prevent bacterial infection in perioperative period, but are also responsible for the most allergic reactions that appears in this period. Therefore, a much researched problem is represented by the cross-reactivity between different classes of betalactams [23]. Cephalosporins, semisynthetic derivates from cephalosporin C, usually classified according to a generation (first to fifth), were firstly described in 1960s and are the most used antibiotics nowadays $[24,25]$. They have a stable structure made up of a beta-lactam ring, with four atoms, linked to a sulfurcontaining dihydrothiazine ring, resulting a 7-aminocephalosporinic acid nucleus. This ring has two additional side chains (R1 and R2) which categorize the cephalosporins $[25,26]$. Cefuroxime is a second-generation cephalosporin and it has a methoxyimino group at R1 side chain [27]. Studies have shown that the R2 side chain is not involved in allergic reactions, due to the fact that it is usually lost when the beta-lactam ring is opened. So, the R1 side chain is the main determinant of immunological reactions to cephalosporins [27]. But, being able to predict cross-reactivity between different classes of cephalosporins (which varies from 0\%-68.8\% [28]) is difficult because the reactivity may be linked to the entire molecule, not only to the R1 side chain [26].

It is known Cephalosporin skin test aren't standardized, so there can be false-positive or false-negative test [25]. A skin test can locally produce an Ig-E or T-cell mediated allergy. The skin tests for betalactams are very sensitive for immediate hypersensitivity reactions. But, like for our patient, a negative skin test result doesn't exclude the chance of appearance of an immediate-type allergy [3,29]. In the perioperative period, the skin test can also be falsepositive due the multitude of administered drugs [30,31]. Even so, it remains a strong recommendation to perform a skin test in order to evaluate a drug hypersensitivity reaction. For cephalosporins, the recommended nonirritating test concentration, for intradermal test, is $2 \mathrm{mg} / \mathrm{mL}$ [29].

There are multiple systemic disturbances produced by a drug allergy and they are felt even more severely in patients with previous associated pathologies [32-34]. Our patient developed cardiac arrest, followed by severe pulmonary and renal injury, important acid-base disturbances refractory to usual drugs. She was in need for vasopressor and inotrope support for few days, needed prolonged mechanical ventilation due to extremely severe acute respiratory distress syndrome and should underwent renal replacement therapy in order to correct the severe acidosis and acute kidney failure.

As we presented before, almost two-thirds of patients with anaphylactic shock develop cardio-vascular events [2]. In our case, the exact mechanism of cardiac arrest during hard to prove because there is an entire panel of cardio-vascular manifestation which can lead to this, such as increased generalized vascular permeability with severe vasodilatation and secondary reduction in circulating blood volume and consecutive coronary artery hypoperfusion. It can induce myocardial injury through hypoxemia followed by cardiac arrest [1]. Otherwise, the appearance of a Kounis syndrome can be possible related to the fact that there are mast cells in the coronary artery wall and they can be activated, with secondary release of numerous mediators, leading to vasospasm associated with hypoperfusion, hypooxygenation and secondary ischemic manifestations, especially in patients with previous coronary atheromatosis [19].

There is an increase number of Kounis syndrome described in literature in the last few years and Cefuroximeaxetil represent the main allergic drug. Therefore, now is described a type III variant of the syndrome, besides the two types presented by Kounis in 1991, in patients with drug-eluting coronary stent thrombosis [35]. After multiple investigations, our patient was diagnosed with type II Kounis syndrome secondary to an anaphylactic shock induced by Cefuroxime-axetil intravenous test. After two weeks from de incident, she recovered the previous cardiac function with an ejection fraction of the left ventricle within the normal limits for her age. Type II variant of Kounis syndrome refers to patients with pre-existing coronary artery problems (even though it is silent) and atherosclerosis. In the presence of an anaphylactic event, with secondary inflammatory mediators' release, it can appear vasospasm, atheromatous plaque erosion or rupture that manifests like a myocardial infarction $[12,36,37]$. Ridella and al. have been highlighted the fact that, in case of Kounis syndrome, the right coronary artery is especially affected by vasospasm and the patients usually develop inferior myocardial ischemia or infarction [13]. Also, in our case, the inferior myocardial wall was the most severe affected.

The kidneys are also severely affected in case of anaphylactic shock associated with cardiac arrest and prolonged resuscitation. In patients with chronic renal injury, the impact is felteven more drastic [8,38-40]. Leong and al. have described a case of acute renal failure by interstitial nephritis after Cefuroxime-axetil administration [9].

Anaphylactic shock and acute respiratory distress syndrome in case of cefuroxime-axetil administration are rare is a life-threatening situation, usually with refractory hypoxemia and hypercapnia [41,42]. It appears within one week from the trigger event [43]. Our patienthas developed acute respiratory failure, with diffuse lug inflammation and multiple bilateral diffuse opacities on chest X-ray examination. The only salvage therapy in our case was putting her in prone position for $12 \mathrm{~h}$, with secondary rapid improvements in gas exchanges and systemic hemodynamics. Various studies have shown important decreased in mortality rate in case of prone position use [44]. Moerer and al. have shown that prone positioning has an important role in cases with refractory hypoxemia, and in combination with recruitment maneuvers, can improve patient's outcome [45]. 


\section{Conclusions}

Cefuroxime is one of the most used antibiotics in perioperative period and can produce life-threatening allergic reactions. A negative skin test does not exclude an immediate hypersensitive reaction. Cefuroxime can be responsible for allergic reactions that can lead to coronary vasospasm and cardiac arrest. All the clinicians should be aware of the existence of Kounis syndrome and to manage it accordingly. The management of an anaphylactic shock is very difficult and complex in some case, especially related with its consequences, like cardiac and pulmonary injuries or renal sequels and multidisciplinary approach is indicated.

\section{References}

1.ABSMAIER, M., BIEDERMANN, T., BROCKOW, K., J. Allergy Clin. Immunol. Pract., 2018

2.WORM, M., EDENHARTER, G., RUEFF, F., SCHERER, K., PFÖHLER, C., MAHLER, V., TREUDLER, R., LANG, R., NEMAT, K., KOEHLI, A., NIGGEMANN, B., Allergy, 67, nr. 5, 2012, p. 691

3.CHRISTIANSEN, I.S., KRØIGAARD, M., MOSBECH, H., SKOV, P.S., POULSEN, L.K., GARVEY, L.H., Clin. Exp. Allergy, 45, nr. 4, 2015, p. 807 4.BASSETTI, M., RIGHI, E., ASTILEAN, A., CORCIONE, S., PETROLO, A., FARINA, E.C., DE, F.R., Minerva Anestesiol., 81, nr. 1, 2015, p. 76 5.AUSTEN, K.F., In Harrison's Principles of Internal Medicine; $16^{\text {th }}$ ed.; McGraw- Hill Companies, Inc. United States, 2005, p. 1947

6.KELKAR, P.S., LI, J.T., N. Engl. J. Med., 345, nr. 11, 2001, p. 804

7.NECHITA, A.M., PITURU, S., RADULESCU, D., PERIDE, I., NEGREANU, L., NICULAE, A., FERECHIDE, D., CHECHERITA, I.A., SINESCU, R.D., Farmacia, 64, nr. 3, 2016, p. 348

8.DEL VILLAR-GUERRA, P., MORENO VICENTE-ARCHE, B., CASTRILLO BUSTAMANTE, S., SANTANA RODRIGUEZ. C., Internat. J. Immunopathol. Pharmacol., 29, nr. 4, 2016, p. 731

9.LEONG, C.L., THIRUVENTHIRAN, T., Nephron., 84, nr. 2, 2000, p. 185 10.NICULAE, A., DAVID, C., DRAGOMIRESCU, R.F., PERIDE, I., TURCU, F.L., PETCU, L.C., COVIC, A., CHECHERITA, I.A., Rev. Chim. (Bucharest), 68, no. 2, 2017, p. 354

11.KOUNIS, N.G., ZAVRAS, G.M., Br. J. Clin. Pract., 45, nr. 2, 1991, p. 121

12.MITSIS, A., CHRISTOdOULOU, E., GEORGIOU, P., Eur. Heart. J. Acute Cardiovasc. Care., 2017

13.RIDELLA, M., BAGDURE, S., NUGENT, K., CEVIK, C., Inflamm. Allergy Drug Targets, 8, nr. 1, 2009, p. 11

14.BITEKER, M., DURAN, N.E., BITEKE,R F.S., ERTURK, E., AYKAN, A.Ç., CIVAN, H.A., ÖZKAN, M., Int. J. Cardiol., 136, nr. 1, 2009, p. 3 15.MYTAS, D.Z., STOUGIANNOS, P.N., ZAIRIS, M.N., TSIAOUSIS, G.Z., FOUSSAS, S.G., HAHALIS, G.N., KOUNIS, N.G., PYRGAKIS, V.N., Int. J. Cardiol., 134, nr. 3, 2009, p. 129

16.KOGIAS, J.S., PAPADAKIS, E.X., TSATIRIS, C.G., HAHALIS, G., KOUNIS, G.N., MAZARAKIS, A., BATSOLAKI, M., GOUVELOUDELIGIANNI, G.V., KOUNIS, N.G., INT. J. CARDIOL., 139, NR. 2, 2010, P. 206

17.SOUFRAS, G.D., KOUNIS, G.N., CHILADAKIS, J.A., KOUNIS, S.A., GOUVELOU-DELIGIANNI, G.V., BATSOLAKI, M., KOUNIS, N.G., Dermatol., 219, nr. 1, 2009, p. 87

18.NIKOLAIDIS, L.A., KOUNIS, N.G., GRADMAN, A.H., Can. J. Cardiol., 18, nr. 5, 2002, p. 508

19.KOUNIS, N.G., Int. J. Cardiol., 110, nr. 1, 2006, p. 7

20.MAZARAKIS, A., KOUTSOJANNIS, C.M., KOUNIS, N.G., ALEXOPOULOS, D., Acta Cardiol., 60, nr. 3, 2005, p. 341
21.BITEKER, M., DURAN, N.E., BITEKER, F.S., GUNDUZ, S., GOKDENIZ, T., KAYA, H., ASTARCYODLU, M.A., ÖZKAN, M., J. Am. Geriatr. Soc., 56, nr. 9, 2008, p. 1757

22.MURAT, S.N., KARASU, B.B., ORNEK, E., AKDEMIR, R., Int J Cardiol., 151, nr. 2, 2011, p. 53-55

23.ROMANO, A., GAETA, F., VALLUZZI, R.L., MAGGIOLETTI, M., ZAFFIRO, A., CARUSO, C., QUARATINO, D., J. Allergy Clin. Immunol., 136, nr. 3, 2015, p. 685

24.VAN BOECKEL, T.P., GANDRA, S., ASHOK, A., CAUDRON, Q., GRENFELL, B.T., LEVIN, S.A., LAXMINARAYAN, R., Lancet Infect. Dis., 14, nr. 8, 2014, p. 742

25.KIM, M.H., LEE, J.M., Allergy Asthma Immunol., 6, nr. 6, 2014, p. 485 26.YUSON, C.L., KATELARIS, C.H., SMITH, W.B., Austr. Prescr., 41, nr. 2,2018, p. 37

27.ANTUNEZ, C., BLANCA-LOPEZ, N., TORRES, M.J., MAYORGA, C., PEREZ-INESTROSA, E., MONTANEZ, M.I., FERNANDEZ, T., BLANCA, M., J. Allergy. Clin. Immunol., 117, nr. 2, 2006, p. 404

28.ATANASKOVIC MARKOVIC, M., VELIEKOVIC, T.C., GAVROVIC JANKULOVIC, M., VUĖKOVIC, O., NESTOROVIC, B., Pediatr. Allergy Immunol., 16, nr. 4, 2005, p. 341

29.BROCKOW, K., GARVEY, L.H., ABERER, W., ATANASKOVIC MARKOVIC, M., BARBAUD, A., BILO, M.B., BIRCHER, A., BLANCA, M., BONADONNA, B., CAMPI, P., CASTRO, E., Allergy, 68, nr. 6, 2013, p. 702

30.TIGLIS, M., GRINETESCU, I.C., NEAGU, T.P., TURCU, F.L., COCOLOS, A.M., GRINETESCU, I.M., Rev. Chim. (Bucharest), 69, nr. 2, 2018, p. 391

31.AURICH, S., SCHUURMANN, M., SIMON, J.C., TREUDLER, R., J. Dtsch. Dermatol. Ges., 15, nr. 6, 2017, p. 668

32.VASIC, J., PETRANOVA, T., POVOROZNYUK, V., BARBU, C.G., KARADZIC, M., GOJ KOVIC, F., ELEZ, J., WINZENRIETH, R., HANS, D., CULAFIC VOJ INOVIC, V., Poiana, C., J. Bone Miner. Metab, 32, nr. 5, 2014, p. 556

33.NICULAE, A., PERIDE, I., VACAROIU, I., DAVID, C., DRAGOMIRESCU, R., RADULESCU, D., CHECHERITA, I.A., Nephrol. Dial. Transplant., 31, nr. 1 Suppl., 2016, p. 1416

34.POIANA, C., CARSOTE, M., ARDELEANU, C., TERZEA, D., AVRAMESCU, E.T., NEAMTU, M.C., MIULESCU, R.D., Rom. J. Morphol. Embryol., 52, nr. 1, 2011, p. 187

35.AKYEL, A., MURAT, S.N., CAY, S., KURTUL, A., OCEK, A.H., CANKURT, T., Int. J. Cardiol., 155, nr. 3, 2012, p. 461

36.DAVID, C., BOVER, J., VOICULET, C., PERIDE, I., PETCU, L.C., NICULAE, A., COVIC, A., CHECHERITA, I.A., Int. Urol. Nephrol., 49, nr. 4, 2017, p. 689

37.BITEKER, M., Int. J. Cardiol., 145, nr. 3, 2010, p. 553

38.CHECHERITA, I.A., DAVID, C.R., DIACONU, V., CIOCALTEU, A., LASCAR, I., Rom. J. Morphol. Embryol., 52, nr. 3 Suppl., 2011, p. 1047 39.COLAK, S., KUTLUCAN, L., ERDOGAN, M.O., AFACAN, M.A., SARITAS, A., KANDIS, H., J. Coll. Physicians Surg. Pak., 25, nr. 4, 2015, p. 310 40.CHECHERITA, I.A., DAVID, C., STOICA, L., POPESCU, P., CIOCALTEU, A., LASCAR, I., Rom. J. Morphol. Embryol., 52, nr. 2, 2011, p. 533 41.GREENBERGER, P.A., DITTO, A.M., In Allergy Asthma Proceed., 33, 2012

42.VAILLANT, A.A., ZITO, P.M., Stat Pearls Publish., 2018

43.CHERIAN, S.V., KUMAR, A., AKASAPU, K., ASHTON, R.W., APARNATH, M., MALHOTRA, A., Resp .Med., 2018

44.J OHNSON, N.J ., LUKS, A.M., GLENNY, R.W., Resp. Care., 62, nr. 8, 2017, p. 1097

45.MOERER, O., TONETTI, T., QUINTEL, M., Curr. Opin. Crit. Care., 23, nr. 1, 2017, p. 52

$\overline{\text { Manuscript received: } 28.08 .2018}$ 